\title{
Modulatory Effects of Berberine Chloride on Lipid Profile, Oxidant Status and Insulin Signaling Molecules in Streptozotocin Induced Diabetic Rats
}

\author{
Govindasami Chandirasegaran $^{1}$ (D) Chakkaravarthy Elanchezhiyan ${ }^{1}$. \\ Kavisa Ghosh ${ }^{2}$
}

Received: 1 October 2017/Accepted: 24 April 2018/Published online: 21 May 2018 (C) Association of Clinical Biochemists of India 2018

\begin{abstract}
The goal of the present study was to evaluate the effect of Berberine chloride (BC) on lipid profile, oxidant status and insulin signaling molecules in Streptozotocin (STZ) induced diabetic rat model. Diabetes was induced in rats by a single dose of intraperitoneal administration of STZ (40 mg/kg b.w). Diabetic rats were treated with BC $(50 \mathrm{mg} / \mathrm{kg} \mathrm{b.w})$ and glibenclamide $(6 \mathrm{mg} / \mathrm{kg} \mathrm{b.w})$ for 45 days. BC treated diabetic rats showed significant $(p<0.05)$ decrease in the levels of TC, TG, phospholipi 's, LDL, VLDL and lipid peroxidation markers such as $\mathrm{J}$ and TBARS. An increase in enzymatic antioxidant (s ', CAT and GPx), non-enzymatic antioxidant ( $\mathrm{G}^{\mathrm{C}} \mathrm{T}$, vitam. $\mathrm{C}$ and E) and insulin signaling molecules es pres n, like Insulin receptor substrate-1 (IRS-1), Prot - in kinase b ${ }^{\top} \mathrm{KB}$ or Akt) and glucose transporter-4 (GLI T-4) were found to be significantly raised in $\mathrm{BC}$ treated $\mathrm{S}$ induced diabetic rats. Thus, the results of the ci ment stury demonstrated that BC significantly reversed the $\mathrm{b}_{1}, \mathrm{~A}$ levels of lipids, oxidant status and insulin nalin molecules in the diabetic rat model, which ay a con rributed to its anti-diabetic and antioxidanact ies.

Govina "

g-ndrus@gmail.com

Cha ravavarhy Elanchezhiyan
zhryanzooau@gmail.com
Kay.a Ghosh
kavisa9@gmail.com

1 Department of Zoology, Annamalai University, Annamalainagar, Tamil Nadu 608 002, India

2 Unit of Toxicology, Department of Zoology, School of Life Sciences, Bharathiar University, Coimbatore, Tamil Nadu 641 046, India
\end{abstract}

Keywords Berberine chlon $\%$ Antioxidant · Insulin receptor substr te a d Glucose transporter

\section{Introduct}

- hetes meritus (DM) is a condition with a complex and mu arious group of disorders associated with high level $f$ bl od sugar over an extended period. It results from s. tage or lack of insulin secretion or reduced sensitivity of the tissue to insulin [1]. Current reports reveal that Globally 415 million people suffer from diabetes. It is predictable to increase to 642 million people in 2040. In India alone, 69.2 million people are suffering from diabetes, and this will increase to 123.5 million in 2040 [2]. Diabetes mellitus has been associated with an increased risk of mortality and prevalence of cardiovascular disease. Oxidative stress may occur as a consequence of abnormalities in glucose and lipid metabolism, which favor hyperglycemia and dyslipidemia. These phenomena are coupled with developing of atherosclerosis and cardiovascular complications in the diabetic patients [3, 4].

In diabetic patients, hyperglycemia arises due to defects in the body's ability to control glucose and insulin homoeostasis. Both the regulation of glucose uptake as well as it's utilization is critical for the normal maintenance of glucose homoeostasis. Insulin plays a significant role in controlling the rates of glucose uptake, glycogen synthesis and glycolysis in the peripheral tissues. It is well known that the glucose uptake is regulated by glucose transporter (Glut-4) in the plasma membrane of cells [5].

An important organ for insulin response is skeletal muscle. Under normal conditions, insulin when bound to its receptor, leads to IR tyrosine kinase activation, that can activate a cascade of various phosphorylation- 
dephosphorylation reactions, including phosphatidylinositol-3-kinase (PI3K-p85), serine/threonine kinases Akt/PKB (e.g.Ser-473 and Thr-308 for the Akt/PKB isoform), which lead to GLUT-4 translocation and intracellular glucose metabolism [6, 7]. In patients with type 2 diabetes, defects in insulin-stimulated glucose metabolism in skeletal muscle have also been attributed to impaired glucose transport [8], glycogen synthesis [9] and glycogen synthase activation [10]. These defects may result from impaired insulin signal transduction [11]. Ameliorating insulin resistance is an important strategy in the development of new pharmacological treatment for type 2 diabetes. Previously Chandirasegaran et al. [12] reported that BC has ameliorating and anti-diabetic activities in STZ induced diabetic rats. The present work was designed to evaluate the modulatory effects of $\mathrm{BC}$ on insulin signaling molecules in skeletal muscles and on the levels of lipid profile and oxidant status in STZ induced diabetic rats.

\section{Materials and Methods}

\section{Chemicals}

Berberine chloride and Streptozotocin were procured from Sigma-Aldrich (St. Louis, MO, USA). The primary antibodies IRS1, Akt and insulin, were procured from San Cruz Biotechnology, Inc., USA and GLUT-4 was purchased from Abcam. All other chemicals as well a reagents used were of analytical grade and wer nurchaso from Merck, Himedia, Mumbai and India.

\section{Experimental Animals}

About 180-200 g of male albino ' $\mathbf{v} /$ istar rats were obtained from Central Animal House, Facurt Medicine, Rajah Muthiah Medical College nnam alai University. All the rats were housed in cl pr varbonate cages under constant $12 \mathrm{~h}$ light an ${ }^{\prime}$ lark cle $25 \pm 2{ }^{\circ} \mathrm{C}$ room temperature. Througho's he expe ment, rats were feed with standard rodent pello od (Hindustan Lever Ltd, Mumbai, India) an tap water provided with ad libitum. The experime as ac epted by the Animal Ethics Committee of $\mathrm{P}$ Mu ${ }_{1}$ Medical College and Hospital (Reg. No 1 /19 a/CPCSEA, Proposal No. 1085).

\section{Induc on of Diabetes}

Diabetic rat model was created by administrating a single dose (in fasting condition) of freshly prepared solution of STZ (40 mg/kg b.w) in a $0.1 \mathrm{M}$ citrate buffer with $\mathrm{pH} 4.5$ [13]. Then STZ treated rats were allowed to drink 5\% glucose water for preventing the STZ induce hypoglycemia
$[13,14]$. After $72 \mathrm{~h}$, blood was collected from STZ injected rats, and the level of blood glucose was measured. Rats with of blood glucose level above $230 \mathrm{mg} / \mathrm{dl}$ were considered for further study.

\section{Experimental Design}

In the present study, a total of 24 rats were randomly divided into four groups ( 6 control and 18 diabet - rats) and each group having six rats. Based on previo cpor s Chandirasegaran et al. [15] BC was intragas only administered at a concentration of $5 \mathrm{gg} / \mathrm{kg} / \mathrm{W}$ and glibenclamide at a concentration of $0 \mathrm{mg} / \mathrm{k}_{\varepsilon} \quad \mathrm{w} /$ Both the drugs were suspended in distilled vater. The groups are as follows:

Group 1 Normal contro-rats

Group 2 STZ (40 m ody - bght)-induced diabetic control rats

Group 3 Diab al ats + B $C$ ( $50 \mathrm{mg} / \mathrm{kg}$ b.w $)$ treated rats

Group 4 Dia tic $\perp$ Glibenclamide (Reference

drug) $\mathrm{mg} / \mathrm{kg} \mathrm{b.w)} \mathrm{treated} \mathrm{rats}$

Every aus anhing BC (50 mg/kg b.w) and glibenclamide (6 mg/kg b.w) were given to diabetic rats by - ngastric Mtubation for 45 days. On the 45th day, animan vere sacrificed by cervical dislocation. The blood mp es were collected in two tubes, i.e. one with an a. coagulant for separation of plasma and another without anticoagulant for serum separation. After the separation of plasma, the buffy coat enriched in white cells was detached, and the residual erythrocytes were washed three times with physiological saline and made up to a known volume. A specific volume of erythrocyte was lysed with hypotonic phosphate buffer at $\mathrm{pH}$ 7.4. The hemolysate was separated by centrifugation at $2500 \mathrm{rpm}$ for $10 \mathrm{~min}$, and the supernatant was used for the estimation of enzymatic antioxidants. Skeletal muscle was harvested for western blot analysis.

\section{Biochemical Analysis}

The lipid profile parameters such as total cholesterol [16], HDL cholesterol [17] and triglycerides [18] were estimated respectively. The level of serum LDL cholesterol and VLDL cholesterol were estimated [19]. Phospholipid was determined by the method of Zilversmit and Davis [20].

TBARS and $\mathrm{LOOH}$ in the plasma were measured by the method of Ohkawa [21]. SOD was evaluated by the method of Kakkar [22]. CAT was measured by the method given by Sinha [23]. GPx was evaluated by the method given by Rotruck [24]. GSH was assessed by the method of Ellman [25]. Vitamin C and E were evaluated by Omaye et al. [26] and Baker et al. [27] respectively. 


\section{Western Blotting Analysis}

The total protein from tissues were extracted by homogenizing tissues with $1 \mathrm{ml}$ of a buffer containing $10 \mathrm{mM}$ HEPES (pH 7.9), $10 \mathrm{mM} \mathrm{KCl}, 0.1 \mathrm{mM}$ EDTA, $0.1 \mathrm{mM}$ EGTA, $1 \mathrm{mM}$ DTT, $0.5 \mathrm{mM}$ PMSF, and $10 \mu \mathrm{l}$ protease inhibitor cocktail. The lysate was then centrifuged at $8000 \times g$ for $2 \mathrm{~min}$ at $4{ }^{\circ} \mathrm{C}$, the supernatant was removed, and aliquots were frozen at $-80{ }^{\circ} \mathrm{C}$. The total protein concentration of the supernatant was determined by the method of Lowry et al. [28]. SDS-PAGE was performed using equivalent protein extracts $(50 \mu \mathrm{g})$ from each sample. The resolved proteins obtained were then electrophoretically transferred to poly vinylidene difluoride membranes. The blots were incubated in $1 \times$ PBS containing 5\% non-fat dry milk for $2 \mathrm{~h}$ to block nonspecific binding sites. The blots were further incubated with 1:200 dilution of primary antibodies overnight at $4{ }^{\circ} \mathrm{C}$. After washing, the blots were transferred and incubated with 1:1000 dilution of horseradish peroxidase-conjugated secondary antibody for $45 \mathrm{~min}$ at room temperature. After continuous washes with high and low salt buffers, the immunoreactive proteins were visualized using enhanced chemiluminescence detection reagents (Sigma-Aldrich). Densitometry was performed on IISP flat bed scanner and quantitated with Total Lab 1.11 software.

\section{Statistical Analysis}

All the data were analyzed by one-way analysic $f$ varian (ANOVA) followed by Tukey multiple comp riso ests by using a commercially available statistic sortware pu Kage (IBM SPSS Statistics for Windows, rsion 15). Results were presented as mean $\pm \mathrm{SD}$ of six $\mathrm{in}$ each group. The value of $p<0.05$ was o nsiderea as statistically significant.

\section{Results}

Lipid Profile in Co. ol and Treated Rats

The diab conti lol rats depicted a rise in the levels of TC $\mathrm{T}, \mathrm{p}_{\mathrm{H}}$ nolipids, LDL and VLDL, whereas a C line in HDL level was observed when compared with non control rats. Oral treatments of diabetic animals with $1 C$ and glibenclamide significantly restored the abnormal levels of TC, TG, phospholipids, LDL, VLDL and HDL when compared with diabetic control rats. The result of $\mathrm{BC}$ was also found to be similar in effectiveness and was comparable with glibenclamide treatment (Table 1).

\section{Glycogen Level in Muscle Tissues of Control and Treated Rats}

Figure 1 shows the level of muscle glycogen in normal and diabetic animals. The level of muscle glycogen was reduced in diabetic control rats when compared to normal control rats. Treatment of BC significantly improved the muscle glycogen levels in diabetic rats when compared to diabetic control rats.

\section{Lipid Peroxidation Markers in Control and Tre. Rats}

Figure 2 displays the level of TB $\mathrm{RS}$ and LLOH in control and experimental rats. There as a significant elevation in the level of TBARs L L in the of diabetic control rats wh com ad with normal control rats. The oral treatr en $f B C$ and glibenclamide were successful in bringing these cormal levels of TBARS and LOOH back to near hormal in diabetic rats.

\section{Enzymatic Antiox ants in Control and Treated Rats}

enzym ac antioxidant such as SOD, CAT and GPx acti $y$ of control and experimental rats are represented in ig. There was a significant reduction of SOD, CAT and c. activity in erythrocytes of diabetic control rats as compared with normal control rats. Continuous treatments of $\mathrm{BC}$ or glibenclamide had significantly improved the activities of SOD, CAT and GPx in erythrocytes of diabetic rats.

\section{Non-enzymatic Antioxidants in Control and Treated Rats}

Figure 4 shows the level of non-enzymatic antioxidants such as GSH, vitamin $\mathrm{C}$ and $\mathrm{E}$ in plasma of control and experimental rats. In diabetic control rats, the level of $\mathrm{GSH}$, vitamin $\mathrm{C}$ and vitamin $\mathrm{E}$ were significantly declined as compared with normal control animals. However, $\mathrm{BC}$ or glibenclamide treatment had significantly enhanced the level of GSH, vitamin C and $\mathrm{E}$ in plasma of diabetic rats as compared with diabetic control rats.

\section{Western Blot Analysis of IRS 1, Akt and GLUT 4 in Skeletal Muscle of Control and Treated Rats}

Figure 5 illustrates the protein expression study of IRS1, Akt and GLUT-4 in the skeletal muscle of control and experimental rats. The level of IRS1, Akt and GLUT-4 were significantly declined in diabetic control rats. Oral treatment of $\mathrm{BC}$ significantly reverted the diminished 
Table 1 Lipid profile in control and treated rats: diabetic control rats were compared with normal control rats; $\mathrm{BC}$ treated diabetic rats were compared with diabetic control rats. All the data were expressed as the mean \pm SD for 6 rats. The results with different superscripts ( $a, b$, c) in each experimental groups are significantly different at $p<0.05$

\begin{tabular}{lcccccc}
\hline Groups/parameters & TG $(\mathrm{mg} / \mathrm{dl})$ & TC $(\mathrm{mg} / \mathrm{dl})$ & HDL $(\mathrm{mg} / \mathrm{dl})$ & LDL $(\mathrm{mg} / \mathrm{dl})$ & VLDL $(\mathrm{mg} / \mathrm{dl})$ & Phospholipids (mg/dl) \\
\hline Normal control & $52.24 \pm 3.98^{\mathrm{a}}$ & $80.14 \pm 6.10^{\mathrm{a}}$ & $46.10 \pm 3.51^{\mathrm{a}}$ & $23.60 \pm 1.80^{\mathrm{a}}$ & $10.44 \pm 0.80^{\mathrm{a}}$ & $90.23 \pm 6.87^{\mathrm{a}}$ \\
Diabetic control & $126.42 \pm 9.68^{\mathrm{b}}$ & $162.24 \pm 12.42^{\mathrm{b}}$ & $26.64 \pm 2.04^{\mathrm{b}}$ & $110.38 \pm 8.45^{\mathrm{b}}$ & $25.29 \pm 1.94^{\mathrm{b}}$ & $183.18 \pm 14.02^{\mathrm{b}}$ \\
D + BC (50 mg/kg bw) & $79.57 \pm 6.06^{\mathrm{c}}$ & $114.44 \pm 8.71^{\mathrm{c}}$ & $36.23 \pm 2.76^{\mathrm{c}}$ & $62.44 \pm 4.75^{\mathrm{c}}$ & $15.80 \pm 1.20^{\mathrm{c}}$ & $120.08 \pm 9.14^{\mathrm{c}}$ \\
D + GC (6 mg/kg bw) & $66.05 \pm 5.06^{\mathrm{d}}$ & $98.67 \pm 7.55^{\mathrm{d}}$ & $42.84 \pm 3.28^{\mathrm{a}}$ & $41.69 \pm 3.19^{\mathrm{d}}$ & $13.22 \pm 1.01^{\mathrm{d}}$ & $109.65 \pm 8$
\end{tabular}

$D$ diabetic; $B C$ berberine chloride; $G C$ glibenclamide

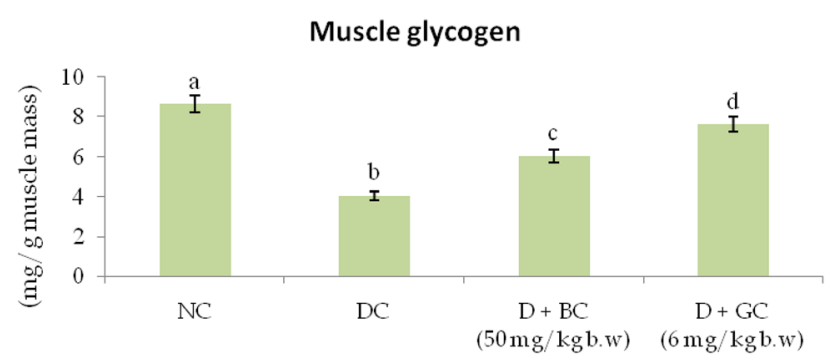

Fig. 1 Glycogen level in muscle tissues of control and treated rats: diabetic control rats were compared with normal control rats; $\mathrm{BC}$ treated diabetic rats were compared with diabetic control rats. All the data were expressed as the mean \pm SD for 6 rats. The results with different superscripts $(\mathrm{a}, \mathrm{b}, \mathrm{c})$ in each experimental groups are significantly different at $p<0.05$ ( $N C$ normal control; $D C$ diabetic control; $D$ diabetic; $B C$ berberine chloride; $G C$ Glibenclamide) levels of IRS1, Akt and GLUT-4 in 1Id ske ql nuscle of diabetic rats.

\section{Discussion}

The majority of in in skeletal mu les. nsulin resistance and impaired insulin secretion are toun to impaired insulin signaling pathway 129, 30. Therefore, in this study, we have investigat $\mathrm{a}$ ther $\mathrm{BC}$ administration improves impaired insulin sigi aling pathway in muscles of STZ induced diarats. It this study, STZ was selected for induction of diau as as the cytotoxic action of STZ mainly destroys $\beta$ lls of the pancreas without affecting other cells by pro-
Fig. 2 Lipid peroxidation markers in control and treated rats: diabetic control rats were compared with normal control rats; $\mathrm{BC}$ treated diabetic rats were compared with diabetic control rats. All the data were expressed as the mean $\pm \mathrm{SD}$ for 6 rats. The results with different superscripts $(a, b, c)$ in each experimental groups are significantly different a $p<0.05$ (NC normal ontrol; $D C$ diabetic contr $1 ;$ iabetic; $B C$ berberine $c$ loride; glibenclamia)

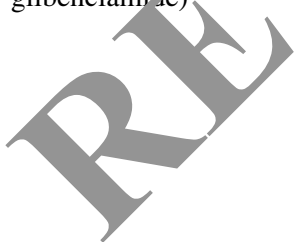

TBARS (Plasma)

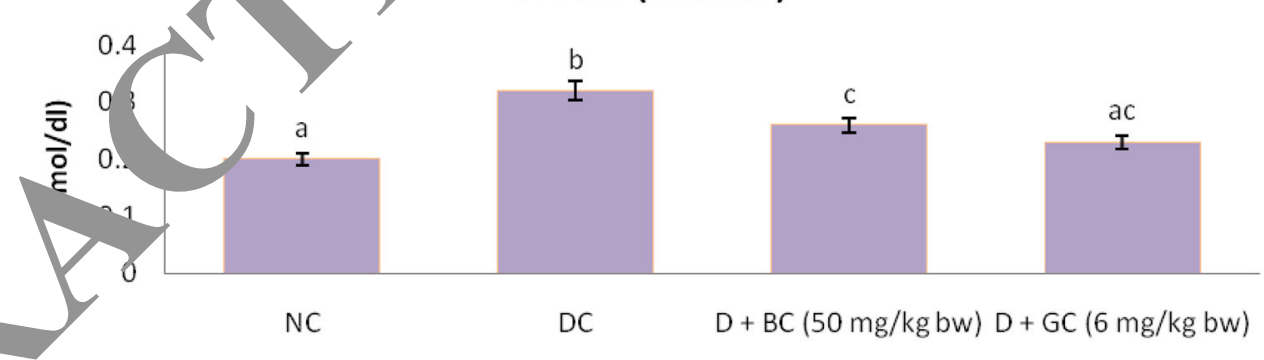

LOOH (Plasma)

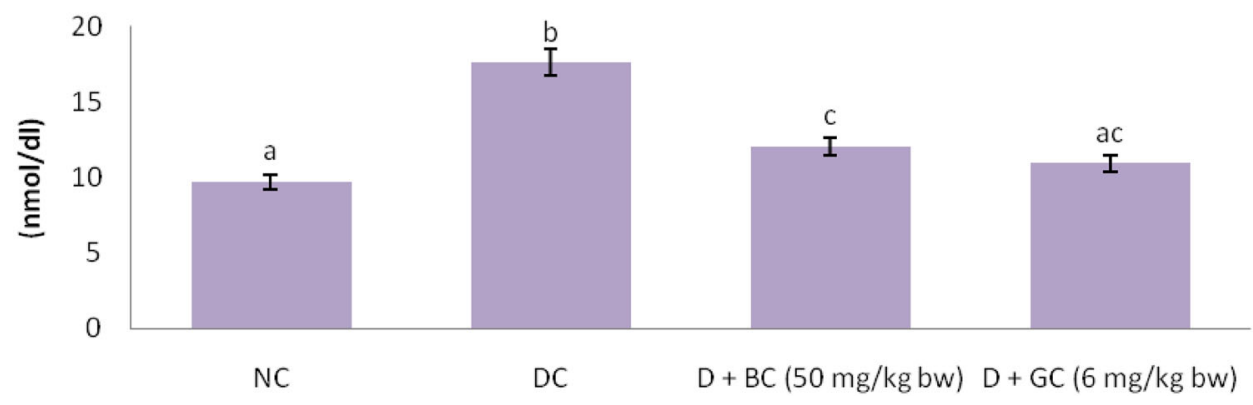


Fig. 3 Enzymatic antioxidants in control and treated rats: diabetic control rats were compared with normal control rats; $\mathrm{BC}$ treated diabetic rats were compared with diabetic control rats. All the data were expressed as the mean \pm SD for 6 rats. The results with different superscripts $(a, b, c)$ in each experimental groups are significantly different at $p<0.05$. (NC normal control; $D C$ diabetic control; $D$ diabetic; $B C$ berberine chloride; $G C$ glibenclamide)

\section{SOD (Erythrocytes)}
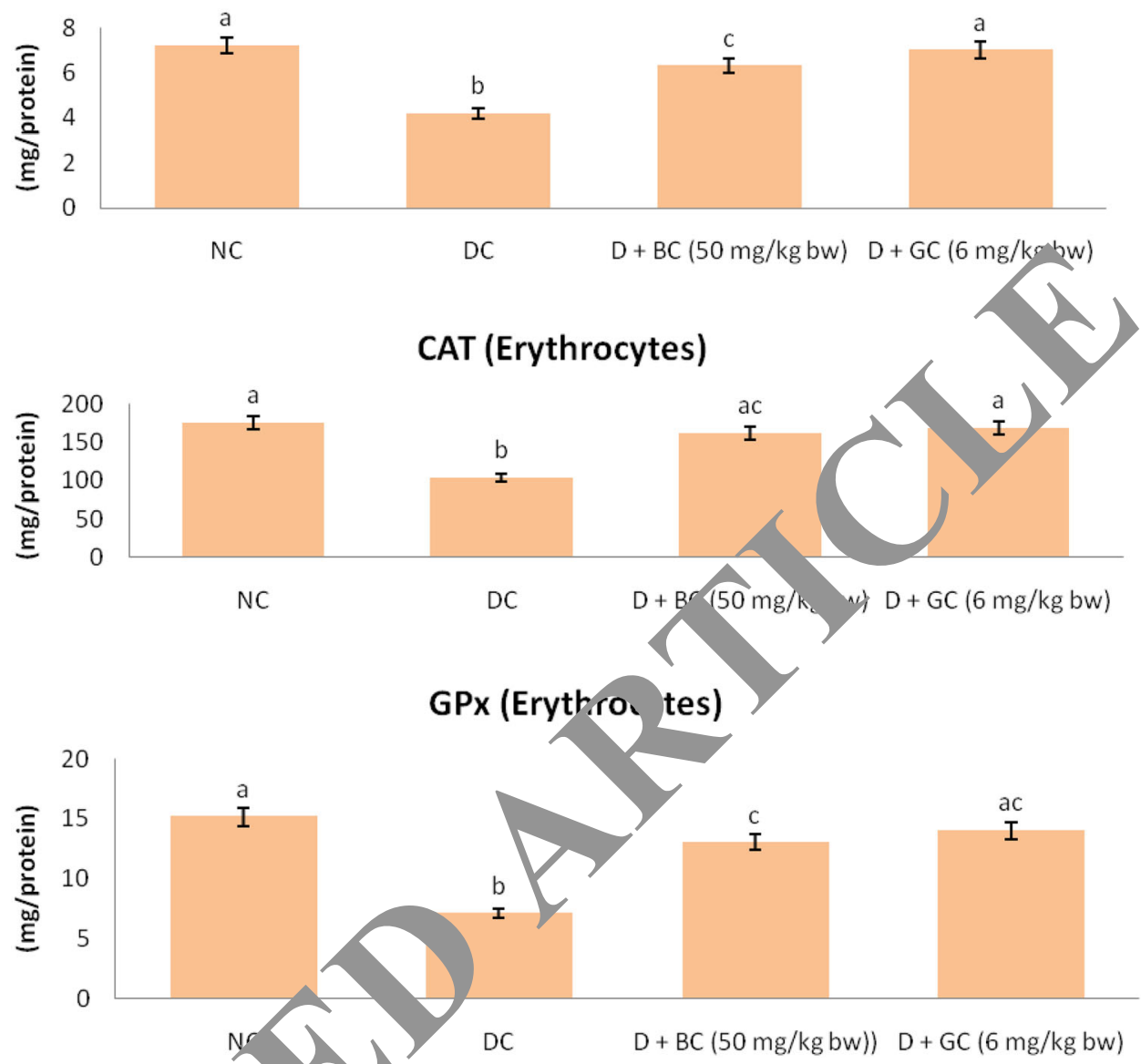

ducing a high level of ROS and carbonium $10\left(\mathrm{CH}^{3+}\right), \quad \mathrm{TG}$, and TC in the serum of STZ treated diabetic control. leading to DNA breaks by alkylation DNA ba and oxidative damage [31]. The dose of $40 \mathrm{ng} / \mathrm{kg}$ b.w. of STZ can induce incomplete destruction of cells of pancreas, which is considered as a type 2 diabetic del $[13,14]$. In our previous study, we obser treatment of $\mathrm{BC}$ significantly reduced blond gluopos and improved the plasma insulin. These 0 rserv ions i vay be due to enhanced insulin secretion in exis treated diabetic $r<[32]$.

In diabetes onc on, hypertriglyceridemia, as well as hyperchole reremia, at he common factors involved in the develop $n t / f$ atherosclerosis and coronary heart disease. These cond. ns c ccur because of lack of insulin secretion, $\mathrm{w}^{\prime}$ ich tivate the lipase enzyme, hydrolyzes triglyceride (1 the fatty acid and glycerol into the circulating ood. The level of the triglyceride was found to be increased in the STZ induced diabetic rats. This may be due to decreased level of insulin, causing a failure to activate lipoprotein lipase, and thus leading to hypertriglyceridemia [33]. STZ induced diabetes is often associated with abnormal lipid metabolism, which is also a metabolic disorder found in diabetic conditions [34]. We observed augmented levels of Several previous studies have stated that LDL is the "bad lipid", and its oxidation can result in increased release of LDL in the arterial walls, resulting in atherosclerotic plaque lesions formation [35, 36]. We observed an increase in serum LDL and VLDL cholesterol fractions along with a decrease in the HDL level in diabetic rats. An increase in the LDL and VLDL cholesterol levels leads to a fall in the HDL level. Treatment with BC and GC helped in restoring the abnormal levels of lipids in diabetic rats. Due to lack of insulin or its action, it leads to inactivation of the lipoprotein lipase in the liver, which is responsible for the change of free fatty acids into phospholipids and cholesterol that is finally released into the blood, resulting in elevated levels of serum phospholipids [37]. The diabetic rats showed a significantly increased level of phospholipids, whereas there was a significant reduction of phospholipids in the serum of BC treated diabetic rats, which may be due to enhanced insulin secretion from the existing $\beta$-cells of the pancreas in diabetic rats. Thus, $\mathrm{BC}$ could be a potential candidate in preventing the formation of diabetes associated complications like atherosclerosis and coronary heart disease. 
Fig. 4 Non-enzymatic antioxidants in control and treated rats: diabetic control rats were compared with normal control rats; $\mathrm{BC}$ treated diabetic rats were compared with diabetic control rats. All the data were expressed as the mean $\pm \mathrm{SD}$ for 6 rats. The results with different superscripts $(a, b, c)$ in each experimental groups are significantly different at $p<0.05$ (NC normal control; $D C$ diabetic control; $D$ diabetic; $B C$ berberine chloride; $G C$ Glibenclamide)
GSH (Plasma)
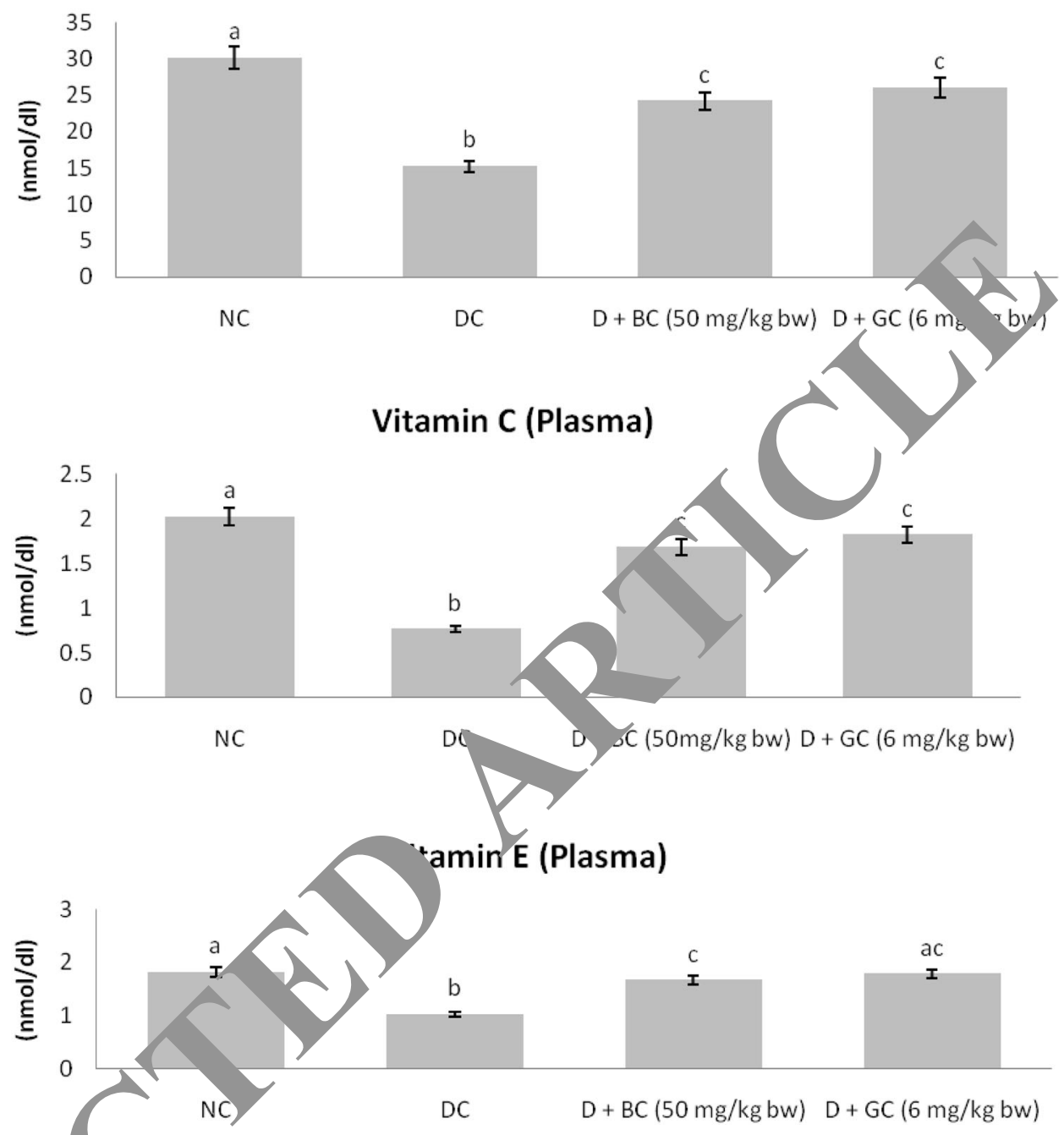

Glycogen is the primary form of in "alar glucose storage and is a branched poly $\ldots$ glucose residues produced by the enzyme glycoren oynthase [38]. Its quantity varies in diffe ent ssues and is a directly influenced by insulin activit. glycogen deposit $\eta$ by stı̀ arting glycogen synthase and inhibiting glyc geh hosphorylase [39]. Muscle glycogen content was significan, reduced in STZ induced diabetic rats. Th; a be due to the increased glycogen phosphorylase activ in alabetes. Continuous oral administration of $B C$ diab, cic rats improved the glycogen content in liv ascles, indicating the possible role of $\mathrm{BC}$ in the modu ion of the glycogen metabolism.

Prolong period of hyperglycemia generates a huge number of ROS which induces oxidative stress. The increase free radicals produced may react with polyunsaturated fatty acids in cell membranes, leading to lipid peroxidation, and in turn result in elevated free radicals production [40]. LPO is a marker of induced oxidative stress in tissues. TBARS and $\mathrm{LOOH}$ are standard lipid peroxidative markers, which are elevated in experimental diabetic rats [41]. In this study, we found that diabetic control rats possess increased levels of TBARS and LOOH in plasma. This result indicated elevated levels of oxidative stress in diabetic control rats. Continuous treatment of $\mathrm{BC}$ significantly declined the increased levels of TBARS and $\mathrm{LOOH}$ in diabetic rats, which may be attributed to its antiperoxidative activity.

Antioxidant enzymes such SOD, CAT and GPx are involved in blocking the free radical process. SOD is the most important scavenging enzyme, which is involved in eliminating free radicals and defends from free oxygen radicals by catalyzing the removal of superoxide radical. This process leads to the prevention of damage to the cell membrane and biological structures [42]. CAT is an antioxidant enzyme which is present in the tissues. It plays a vital role in the decomposition of the hydrogen peroxide molecule, and it prevents the tissues from the reactive 

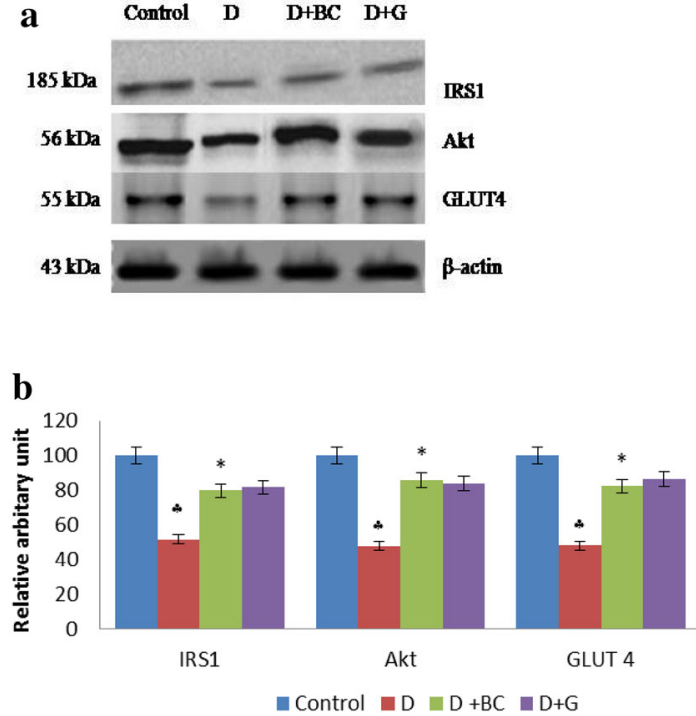

Fig. 5 Western blot analysis of IRS 1, Akt and GLUT 4 in skeletal muscle of control and treated rats: Diabetic control rats were compared with normal control rats; $\mathrm{BC}$ treated diabetic rats were compared with diabetic control rats. a Representative immunoblot analysis. Protein samples $(50 \mu \mathrm{g} / \mathrm{lane})$ resolved on SDS-PAGE was probed with corresponding antibodies. $\beta$-Actin was used as loading control. b Densitometric analysis. The mean protein expression from control lysates for five determinations was designated as $100 \%$ in the graph. Mean \pm SD of six determinants is represented in graph for each group. *Significantly different from untreated control $(p<0.05)$ , *Significantly different from diabetic (D) animals $(p<0.05)$ ( $D$ diabetic; $B C$ berberine chloride; $G C$ Glibenclamide)

hydroxyl radicals [43]. GPx is an enzyme that de roy peroxides, and it plays a vital role to provide ar. tioxidar. defenses to an organism and also involved in the "mination of hydrogen peroxide [44]. In di betes, antio, ddant enzymes SOD, CAT and GPx are ina ivated due to high blood glucose, by glycating of these pro ins, consequently leads to the oxidative stress, w h in turn causes lipid peroxidation. Previously Zhou et 1. to demonstrated BC improves the levels of $\mathrm{C} / \mathrm{OD}$ and GPx in diabetic rats. Thus, the near norma ley $r$ CAT, SOD and GPx activities strongly indicate efficacy of $\mathrm{BC}$ in attenuating the oxidative st $\mathrm{e}$ in diabe, $\mathrm{c}$ rats.

A low le el of $\mathrm{h}$-enzymatic antioxidants has been reported diabetics, which are required to inhibit the peroxidati of liy ds in the cell membrane [46]. Among the tioxic is, GSH protects the cell from toxification bs ca ring ROS [47]. It has been reported that elevated utili ion of GSH in the diabetic cell is one of the reasons for dec,eased level of GSH in diabetics [48]. According to Sadi et al. [49] and Chen et al. [50] Vitamin C protects all lipids from undergoing oxidation, helps to regenerate vitamin $\mathrm{E}$ from its oxidized state and to diminish the count of apoptotic cells. According to Punithavathi et al. [51] vitamin $\mathrm{E}$ reduces the chain reactions, which are associated with lipid peroxidation. Several reports have indicated that the reductions in the levels of non-enzymatic antioxidants are associated with STZ induced diabetic rats [52, 53]. In our studies, BC administration expressed near normal levels of GSH, vitamin $\mathrm{C}$ and $\mathrm{E}$, indicating BC's potential to restore the antioxidant reserves in diabetic animals.

Insulin action is a mediated by binding of insulin to the insulin receptor in target tissues. Consequently, IRS gets activated by the insulin receptor and then exited and phosphorylated the signal molecule PI3K and Bo ? PI3K and Akt can modulate the downstream GLUT-4 [54, 55].

The IRS is a member of the ligand-astiva 4 receptor of tyrosine kinase family, which is a ansmembr, ne signaling protein with several isoforms The oform IRS 1 and IRS 2 are mainly involved in m bolin wulation. IRS- 1 is responsible for glucose netabon and GLUT-4 translocation [56]. A decrea ed 'ular level of IRS1 is associated with insulin resictance anc sufficient insulin secretion [57]. In diabet co rol rats showed remarkably declined levels of IRS1 TH, which indicates insulin resistance found ir diabetio ats. The levels of IRS 1 notably improved in treated groups, which may be due to BC enhanced i sulin sensitivity.

$\mathrm{DKB}$ or $f_{-\mathrm{K} t}$ is a serine/threonine-specific protein kinase that ays a key role in multiple cellular processes, which is tiv led by PI3K. The pathway of PKB activation is a $\mathrm{p}_{1}$ cess that involves membrane translocation as well as phosphorylation. The activation of this enzyme may stimulate glucose transport by triggering translocation of GLUT-4 from the cytosol towards the plasma membrane of the cell [58]. GLUT-4 present in the skeletal, adipose tissue and cardiac muscles plays a critical role in the regulation of glucose homoeostasis through the translocation and activation triggered by insulin [59]. Intracellular GLUT-4 translocates to the plasma membrane and facilitates glucose uptake stimulated by insulin. Under the diabetic condition, PKB and GLUT-4 expression and translocation are reduced due to the impairment of insulin signaling. These alterations lead to a decrease in the consumption of glucose in adipose tissue and skeletal muscles [59-61]. In this study, Akt and GLUT-4 protein expressions were found to be increased in $\mathrm{BC}$ administrated rats compared to diabetic rats. The up-regulation of both Akt and GLUT-4 confirmed increased glucose utilization and thus, help ameliorate the condition of insulin resistance as reported earlier by Nobyuki et al. [62]. Thus, from the above results, it can be concluded that $\mathrm{BC}$ enhanced the level of glucose utilization in skeletal muscles by increasing expression of Akt and GLUT-4, improving insulin sensitivity, and thus, also helped ameliorate the abnormal levels of lipids and antioxidant status, and restored near normal insulin levels in diabetic rats. 


\section{Conclusion}

From this study, it can be concluded that BC can control hyperglycemia, improve the antioxidant status, regulate the abnormal lipid levels and enhances the insulin sensitivity in experimentally induced diabetic rats. Hence, $\mathrm{BC}$ can be a potential drug candidate for the treatment of DM. Further studies in BC would prove helpful in better understanding of its antidiabetic properties and long term effects, which would prove beneficial in preparing potent antidiabetic drugs.

Acknowledgement The authors intend to acknowledge the University Grants Commission, New Delhi, Project File No. 41-178/2012/ (SR) for funding this project work and also extend our thanks to Department of Zoology (UGC - SAP Sponsored), Annamalai University for providing infrastructure facility and support.

\section{Compliance with ethical standards}

Conflict of interest All authors declare that there were no conflicts of interest concerning this publication.

\section{References}

1. Noor AS, Gunasekaran S, Manickam AS, Vijayalakshmi MA. Antidiabetic activity of Aloe vera and histology of organs in Streptozotocin induced diabetic rats. Curr Sci. 2008;94:1070-6.

2. International Diabetes Federation, Diabetes Atlas. 2015.

3. Bray TM. Dietary antioxidants and assessment of ox ative stress. Nutrition. 2000;16:578-80.

4. Chertow B, Edwards JC. Advances in diabetes for the mirenn vitamins and oxidant stress in diabetes and its o plications Medscape Gen Med. 2004;6:1-10.

5. Watson RT, Pessin JE. Intracellular organi zation of insu 1 signaling and GLUT4 translocation. Rec nt Prog Horm Res. 2001;56:175-93.

6. Tanti JF, Grillo S, Grémeaux T, Coffer PJ, Ob'serghen E, Le Marchand- Brustel Y. Potential ro protein kinase B in glucose transporter 4 translocation it ay res. Endocrinology.
1997;138:2005-10.

7. Tan C, Tan Y, Yan W Chen I, Kan hadur R, Wahli W. Smad3 deficiency in mice prou a nsulin resistance and obesity induced by a high-Tat die iabetes. 2011;60:464-76.

8. Ryder JW, Yar saluska b Rincon J, Bjornholm M, Krook A, Lund S, Pedussen Wallberg-Henriksson H, Zierath JR, Holman GD ose of a no impermeable biotinylated photolabeling reager to assess insulin and hypoxia-stimulated cell surface GLUT atent skeletal muscle from type 2 diabetic patients. D tes. - N $9: 647-54$.

Zier h JR, de L, Guma A, Odegoard-Wahlstrom E, Klip A, Henriksson H. Insulin action on glucose transport and p. na membrane GLUT4 content in skeletal muscle from patis nts with NIDDM. Diabetologia. 1996;39:1180-9.

10. Damsbo P, Vaag A, Hother-Nielsen O, Beck-Nielsen H. Reduced glycogen synthase activity in skeletal muscle from obese patients with and without type 2 (non-insulin-dependent) diabetes mellitus. Diabetologia. 1991;34:239-45.

11. Bjornholm M, Kawano $\mathrm{Y}$, Lehtihet M, Zierath JR. Insulin receptor substrate-1 phosphorylation and phosphatidylinositol 3-kinase activity in skeletal muscle from NIDDM subjects after in vivo insulin stimulation. Diabetes. 1997;46:524-7.

12. Chandirasegaran G, Elanchezhiyan C, Ghosh K, Sethupathy S. Determination of antidiabetic compound from Helicteres isora by oral glucose tolerance test. J App Pharm Sci. 2016;6:172-4.

13. Frode T, Medeiros Y. Animal models to test drugs with potential antidiabetic activity. J Ethnopha. 2008;115(2):173-83.

14. Balamurugan R, Duraipandiyan V, Ignacimuthu S. Antidiabetic activity of $\gamma$-sitosterol isolated from Lippia nodiflora $\mathrm{L}$. in streptozotocin induced diabetic rats. Eur J Prormacol. 2011;667:410-8.

15. Chandirasegaran G, Elanchezhiyan C, Ghosh K, up thy 'S. Efficacy of Berberine chloride on hyperglycemia in pto 0 tocin induced diabetic rats. Int Res J Pharm 2016;7:14-

16. Zlatkis A, Zak B, Boyle GJ. A simple meı for dete mination of serum cholesterol. J Clin Med Res 1,53;4 $6-0$ L.

17. Burnstein M, Scholnic HR, Morfin . Rapid met d of isolation of lipoproteins from human serum precipit tion with polyanions. J Lipid Res. 1970;11:58 7.

18. Foster LB, Dunn RT. Stable re nts tor determination of serum triglycerides by a color metric $\mathrm{h}$, $\mathrm{zsch}$ condensation method. Clin Chem. 1973;19. 35, 'O.

19. Friedwald WT, Levy RI, edrickson DS. Estimation of the concentration of $\mathrm{C}$ - $\mathrm{C}$ in pl ma without use of the preparative ultracentrifu Cli Chem. 1972;18:449-502.

20. Zilversmit Bb acro determination of plasma phospholipids by tric oacetic acid precipitation. J Lab Clin Med. 1950;3 -5-60.

21. Ohkaw: $\mathrm{H}$ shi N, YagI K. Assay for lipid peroxidation in animal tisues by thiobarbituric acid reaction. Ann Biochem. 1979;9:53 1-8.

22. kkar P, Das B, Viswanathan PN. A modified spectrophoto$\mathrm{m}$ ric assay of superoxide dismutase. Ind J Biochem Biophys. $1084 ; 21: 130-2$.

2) Sinha AK. Colorimetric assay of catalase. Anal Biochem. 1972;47:389-94.

24. Rotruck JT, Pope AL, Ganther HE. Selenium biochemical role as a component of glutathione peroxidase purification assay. Science. 1973;179:588-90.

25. Ellman GL. Tissue sulfhydryl groups. Arch Biochem Biophys. 1959;82:70-7.

26. Omaye ST, Turnbull JD, Sauberlich HE. Selected methods for the determination of ascorbic acid in animal cells, tissues and fluid. Methods Enzymol. 1979;62:3-11.

27. Baker H, Frank O, Angelis B, Feingold S. Plasma tocopherol in man at various times after ingesting free or acetylated tocopherol. Nutr Rep Int. 1980;21:531-6.

28. Lowry OH, Rosebrough NJ, Farr AL, Randall RJ. Protein measurement with the Folin's-Phenol reagent. J Biol Chem. 1951;193:265-75.

29. Sharma K, Bharti S, Goyal S, Arora S, Nepal S, Kishore K, Joshi S, Kumari S, Arya DS. Upregulation of PPARg by aegle marmelos ameliorates insulin resistance and b-cell dysfunction in high fat diet fed-streptozotocin induced type 2 diabetic rats. Phytother Res. 2011;25:1457-65.

30. Hsu CY, Shih HY, Chang YC, Huang ZL, Tsai MJ, Chia YC, Chen C, Lai YK, Weng CF. The beneficial effects of tetracosanol on insulin-resistance by insulin receptor kinase sensibilisation. J Funct Foods. 2015;14:174-82.

31. Szkudelski T. The mechanism of alloxan and streptozotocin action in beta Cells of the rat pancreas. Physiol Res. 2001;50:536-46.

32. Chandirasegaran G, Elanchezhiyan C, Ghosh K, Sethupathy S. Berberine chloride ameliorates oxidative stress, inflammation and apoptosis in the pancreas of Streptozotocin induced diabetic rats. Biomed Pharmacother. 2017;95:175-85. 
33. Shirwaikar A, Rajendran K, Punitha ISR. Antidiabetic activity of alcoholic stem extract of Coscinium fenestratum in streptozotocin nicotinamide induced type-2 diabetic rats. J Ethnopharmacol. 2005;97:369-74.

34. Krentz AJ. Lipoprotien abnormalities and their consequences for patients with type 2 diabetes. Diab Obes Metab. 2003;5:19-27.

35. Marinangeli CP, Varady KA, Jones PJ. Plant sterols combined with exercise for the treatment of hypercholesterolemia: overview of independent and synergistic mechanisms of action. J Nutr Biochem. 2006;17:217-24.

36. Leiva E, Wehinger S, Guzmán L, Orrego R. 2015. Role of Oxidized LDL in Atherosclerosis, Hypercholesterolemia, Dr. Sekar Ashok Kumar (Ed.). doi:10.5772/59375. http://www.inte chopen.com/books/hypercholesterolemia/roleofoxidized-ldl-inatherosclerosis.

37. Pushparaj PN, Low HK, Manikandan J, Tan BKH, Tan CH. Antidiabetic effects of Cichorium intybus in streptozotocin-induced diabetic rats. J Ethnopharmacol. 2007;111:430-4.

38. Pederson BA, Schroeder JM, Parker G. Glucose metabolism in mice lacking muscle glycogen synthase. Diabetes. 2005;54:3466-73.

39. Chandramohan G, Ignacimuthu S, Pugalendi KV. A novel compound from Casearia esculenta (Roxb.) root and its effect on carbohydrate metabolism in streptozotocin diabetic rats. Eur J Pharmacol. 2008;590:437-43.

40. Lery V, Zaltzber H, Ben-Amotz A, Kanter Y, Aviram M. b-Carotene affects antioxidant status in non-insulin dependent diabetes mellitus. Pathophysiology. 1999;6:157-62.

41. Kakkar R, Kalra J, Mantha SV, Prasad K. Lipid peroxidation and activity of antioxidant enzymes in diabetic rats. Mol Cell Biochem. 1995;151:113-9.

42. Nain P, Saini V, Sharma S, Nain J. Antidiabetic and antioxidant potential of emblica officinalis gaertn leaves extract in Streptozotocin induced type 2 diabetes mellitus (T2M) ats J Ethnopharmacol. 2012;142:65-71.

43. Chance B, Greenstein DS. The mechanism of catalase ac. steady state analysis. Arch Biochem Biophys. 1992 37:301-

44. Chen S, Schopfer P. Hydroxyl radical production $n_{1}$ siologica. reaction. A novel function of peroxidise. Eur J $\mathrm{J}$ chem. 1999;260:726-35.

45. Zhou JY, Zhou SW. Protective effect of $t$ rberine on antioxidant enzymes and positive transcription elong: $n$ factor $b$ express in diabetic rat liver. Fitoterapia. 2011;82:184

46. Opara EC. Oxidative stress, micron nts, diabetes mellitus, and its complications. J R Soc Promot Hea .. J02;122:28-34.

47. Brown LA, Harris FL, Pi D, Ga thier TW. Chronic ethanol ingestion and the risk acut lung in ary: a role for glutathione availability. Alcohol. 2

48. Furfaro AL, Nitt M, Mar , B, Domenicotti C, Cottalasso D, Marinari UM $\mathrm{IL}_{\mathrm{L}}$ ired synth_sis contributes to diabetes-induced decrease in li ver gh hione. Int J Mol Med. 2012;29:899-905.
49. Sadi G, Yılmaz O, Güray T. Effect of vitamin C and lipoic acid on streptozotocin-induced diabetes gene expression: mRNA and protein expressions of $\mathrm{Cu}-\mathrm{Zn}$ SOD and catalase. Mol Cell Biochem. 2008;309:109-26.

50. Chen CY, Milbury PE, Lapsley K, Blumberg JB. Flavonoids from almond skins are bioavailable and act synergistically with vitamins $\mathrm{C}$ and $\mathrm{E}$ to enhance hamster and human LDL resistance to oxidation. J Nutr. 2005;135:1366-73.

51. Punithavathi VR, Anuthama R, Prince PS. Combined treatment with naringin and vitamin $\mathrm{C}$ ameliorates streptozotocip induced diabetes in male wistar rats. J Appl Toxicol. 2008;25:806-13.

52. Pavana P, Sethupathy S, Manoharan S. Antihyperglya a d an ilipidperoxidative effects of tephrosia purpurea seed extrac strep $s$ zotocin induced diabetic rats. Indian J Clin Bio hem. 2007;2 / -83 .

53. Vishnukumar S, Stephan R. Effect of morin ipidper xides and antioxidants in streptozotocin-induced umbetio s. It J Pharm Bio. 2012;3:770-80.

54. Gabriel NV, Hector TG, Sergio HI Iuan JRE Samuel ES, Jose LMF, Ismael LR, Francisco A, J CAP Synthesis in vitro and in silico study of a PP. and Un $\cup$ T-4 modulator with hypoglycemic effect. Bi org Mea 'em Lett. 2014;24:4575-9.

55. Ren ZQ, Zhang PB $\measuredangle$ g XZ, Q, en SK, Zhang H, Lv DT, Zhuang YQW, Ding WC, ang C. Duodenal-jejunal exclusion improves insuli stance in se 2 diabetic rats by upregulating the hepatic i rlin gnaling pathway. Nutrition. 2015;31:733-9.

56. Krentz Krook , jon M, Galuska D, Jiang XJ, Fahlman R, Myers MG, Walı r-Henriksson H, Zierath JR. Characterization of sigi ansduct, on and glucose transport in skeletal muscle from type étic patients. Diabetes. 2000;49:284-92.

57. Leng S, Zhang W, Zheng Y, Liberman Z, Rhodes CJ, EldarFinkelmai $H$. Glycogen synthase kinase 3 beta mediates high cose-induced ubiquitination and proteasome degradation of in lin receptor substrate 1. J Endocrinol. 2010;206:171-81. Z yychova J, Komers R. Emerging role of Akt kinase/protein kinase B signaling in pathophysiology of diabetes and its complications. Physiol Res. 2005;54:1-16.

59. Charron MJ, Katz EB, Olson AL. GLUT4 gene regulation and manipulation. J Biol Chem. 1999;6:3253-6.

60. Egawa K, Maegawa H, Shimizu S, Morino K, Nishio Y, BryerAsh M. Proteintyrosine phosphatase-1B negatively regulates insulin signaling in 16 myocytes and Fao hepatoma cells. J Biol Chem. 2001;276:10207-11.

61. Gandhi GR, Stalin A, Balakrishna K, Ignacimuthu S, Paulraj MG, Vishal R. Insulin sensitization via partial agonism of PPARand glucose uptake through translocation and activation of GLUT4 in $\mathrm{PI} 3 \mathrm{~K} / \mathrm{p}$-Akt signaling pathway by embelin in type 2 diabetic rats. Biochim Biophys Acta. 2013;1830:2243-55.

62. Nobyuki T, Naoto Y, Yuma N, Tetsuya H, Tetsuya N, Astu A, Takaya S. Role of the guanine nucleotide exchange factor in Akt2-mediated plasma membrane translocation of GLUT-4 in insulin-stimulated skeletal muscle. Cell Signal. 2014;26:2460-9. 